\title{
Microbial Patterns and Antimicrobial Susceptibility on Pediatric Patients with Pressure Ulcers
}

\author{
Deryne Anggia Paramita, Khairina Nasution, Nova Zairina Lubis \\ Department of Dermatology and Venereology, Universitas Sumatera Utara, Medan, Indonesia
}

Background: A pressure ulcer (PU) is localized injury to the skin and/or underlying tissue usually over a bony prominence, as a result of pressure, or pressure in combination with sharp surface. Several studies have found that PU is also a common problem in the pediatric population. Infection at PU sites is the most common complication, where PU can host resistant microorganisms and can turn into a local infection that is a source of bacteremia in hospital patients. This study aims to determine the most common bacteria and antimicrobial susceptibility at the site of PU in pediatric patients that serve as baseline data in Haji Adam Malik Hospital.

Materials and Methods: A cross-sectional study was carried out in July-December 2017, involving 30 PU pediatric patients. For each subject, swab from ulcers were cultured in microbial laboratory to determine the microbial pattern and antimicrobial susceptibility.

Results: The most common age group was 0-3 (53.3\%), the highest gender was male (60\%), the most common type was type $2(46.7 \%)$, the main location was occipital (30\%) and the most common undelying diseases were hydrocephalus (16.6\%). The most common microbial pattern in PU pediatric patients is Acinetobacter baumannii (40\%). The highest sensitivity is vancomycine for gram positive bacteria and amikacine for gram negative bacteria.

Conclusion: The most common microbial pattern in PU pediatric patients in Haji Adam Malik Hospital is Acinetobacter baumannii (40\%). The highest sensitivity is vancomycine for gram positive bacteria and amikacine for gram negative bacteria.

Keywords: pressure ulcer, pediatric, microbial pattern, antimicrobial susceptibility

\section{Introduction}

Pressure ulcer (PU) is a localized trauma to the skin and or the underlying tissue usually above the bony prominence, as a result of pressure, or pressure in combination with a sharp surface. ${ }^{1}$ Pressure ulcers are a common clinical problem in hospitalized patients. This problem is associated with physical and psychological burden, increasing morbidity, mortality and increased cost for clinical care. ${ }^{2}$ Data on adult ulcers have received extensive observations while in infant and child populations are not widely known. ${ }^{3}$ Several studies have found that $\mathrm{PU}$ is also a common problem in pediatrics population. ${ }^{4}$ The prevalence of childhood hospital ulcers varies from $3 \%$ to $35 \%{ }^{5}$ In pediatrics population,

Date of submission: October 11, 2018 
the risk factors for the formation of known ulcers include immobility and decreased skin sensitivity. ${ }^{6}$ Regardless, infants or sick children have limitations regarding communication skills so that infants and children are large populations at risk for forming PU.7,8 Discontinuation of skin tissue such as epidermal exfoliation or skin tearing due to friction or plaster especially in neonates and infants in critical conditions will increase the risk of septicemia, complications and high mortality. ${ }^{7}$ Establishment of PU will make the experience of infant, children and families worse due to the impact on self-appearance, extension of hospitalization and formation of infectious complications and the possibility of complex wound care. ${ }^{9}$

Pressure ulcers occur as a result of metabolic processes and active inflammation that starts when sufficient pressure occurs on the skin. Various microorganisms can colonize and then multiply in areas of necrotic tissue that have been destroyed. Such bacterial growth can interfere with the normal process. Even more serious complications can develop if microorganisms penetrate the surrounding tissues. $^{10}$

This study aims to determine the most common bacterial and antimicrobial susceptibility at the site of PU in pediatric patients that serve as baseline data for further study to establish empirical treatment in Haji Adam Malik Hospital.

\section{Materials and methods}

We conducted an observational study. The protocol was approved by Health Research Ethical Committee Medical Faculty of Universitas Sumatera Utara/Haji Adam Malik Hospital No. 278/TGL/KEPK FK USU-RSUP HAM/2017. As many as 30 patients with pressure ulcers from July to December 2017 who were hospitalized at Haji Adam Malik Hospital were eligible for the study, with inclusion criteria namely: PU patients ranging from 0-18 years and free of topical antibiotics at PU sites. Swabbing method was used to collect pus in PU and use swab transport media then sent to the Microbiology Laboratory at Haji Adam Malik Hospital for bacterial culture and antimicrobial susceptibility. The method used for antimicrobial susceptibility testing is MIC and using CLSI 2017 guidelines interpretation.

\section{Results}

The demographic characteristic of PU in pediatric patients are described in Table 1.
Table 1. Characteristics of PU pediatric patients.

\begin{tabular}{|c|c|c|}
\hline \multirow{2}{*}{ Characteristic } & \multicolumn{2}{|c|}{$\begin{array}{c}\text { Pressure Ulcer } \\
\text { Pediatric Patients }\end{array}$} \\
\hline & $\mathbf{n}$ & $\%$ \\
\hline \multicolumn{3}{|l|}{ Age } \\
\hline $0-3$ & 16 & 53.3 \\
\hline$>3-6$ & 1 & 3.4 \\
\hline$>6-9$ & 0 & 0 \\
\hline$>9-12$ & 4 & 13.3 \\
\hline$>12-15$ & 4 & 13.3 \\
\hline$>15-18$ & 5 & 16.7 \\
\hline Total & 30 & 100 \\
\hline \multicolumn{3}{|l|}{ Gender } \\
\hline Male & 18 & 60 \\
\hline Female & 12 & 40 \\
\hline Total & 30 & 100 \\
\hline \multicolumn{3}{|l|}{ Type Pressure Ulcer } \\
\hline Type 1 & 14 & 46.7 \\
\hline Type 2 & 11 & 36.6 \\
\hline Type 3 & 5 & 16.7 \\
\hline Total & 30 & 100 \\
\hline \multicolumn{3}{|l|}{ Location } \\
\hline Femoral & 2 & 6.6 \\
\hline Iliac & 1 & 3.3 \\
\hline Occipitals & 7 & 23.3 \\
\hline Pedi & 1 & 3.3 \\
\hline Sacrum & 6 & 20 \\
\hline Scrotum & 1 & 3.3 \\
\hline Temporalis & 1 & 3.3 \\
\hline Tibia & 1 & 3.3 \\
\hline Genu & 1 & 3.3 \\
\hline Brachial & 2 & 6.6 \\
\hline Gluteus & 4 & 13.3 \\
\hline Lumbalis & 3 & 10 \\
\hline Total & 30 & 100 \\
\hline \multicolumn{3}{|l|}{ Onset (weeks) } \\
\hline $0-2$ & 10 & 33.3 \\
\hline $3-5$ & 15 & 50 \\
\hline $6-8$ & 5 & 16.7 \\
\hline Total & 30 & 100 \\
\hline \multicolumn{3}{|l|}{ Underlying Diseases } \\
\hline Abscess & 4 & 13.3 \\
\hline Acute leukemia lymphoblastic & 1 & 3.4 \\
\hline Fracture & 2 & 6.6 \\
\hline Head injury & 4 & 13.3 \\
\hline Hydrocephalus & 5 & 16.6 \\
\hline Burn wound & 2 & 6.6 \\
\hline Bacterial Meningitis & 1 & 3.4 \\
\hline Post appendicitis & 1 & 3.4 \\
\hline Systemic lupus erythematous & 2 & 6.6 \\
\hline Space occupying lesion intracranial & 1 & 3.4 \\
\hline Osteomyelitis & 1 & 3.4 \\
\hline Osteosarcoma & 1 & 3.4 \\
\hline Sepsis & 3 & 10 \\
\hline Cellulitis & 2 & 6.6 \\
\hline Total & 30 & 100 \\
\hline
\end{tabular}


From Table 1, it is known that the most common patients were in group age $0-3(53.3 \%)$, the most sex was male $(60 \%)$, the most common type was type $2(46.7 \%)$, the main location was occipital $(30 \%)$ and the most common undelying disease was hydrocephalus (16.6\%).

The microbial pattern of $\mathrm{PU}$ in pediatric patients are described in Table 2 below.

Table 2. Microbial pattern in pressure ulcers pediatric patients.

\begin{tabular}{lcc}
\hline \multicolumn{1}{c}{ Organism } & $\mathbf{n}$ & $\mathbf{\%}$ \\
\hline Acinetobacter baumannii & 12 & 40 \\
Staphylococcus aureus & 4 & 13.4 \\
Pseudomonas aeruginosa & 4 & 13.4 \\
Klebsiella pneumonia & 3 & 10 \\
Proteus mirabilis & 2 & 6.7 \\
Burkholdera cepacia & 1 & 3.3 \\
Providencia stuartii & 1 & 3.3 \\
Kocuria kritinae & 1 & 3.3 \\
Enterococcus faecalis & 1 & 3.3 \\
Serratia marcescens & 1 & 3.3 \\
Total & $\mathbf{3 0}$ & $\mathbf{1 0 0}$ \\
\hline
\end{tabular}

From Table 2 above, it is known that Acinetobacter baumannii is the cause with the highest percentage (40\%) respectively amongst the $30 \mathrm{PU}$ pediatric patients.

The sensitivity test amongst gram positive bacterial are described in Table 3. The most sensitive antibiotics from all gram positive bacterial is Vancomycine.

Meanwile, the sensitivity test amongst gram negative bacterial are described in Table 4. Table 4 showed that the most sensitive antibiotics from all gram negative bacterial is amikacine.

\section{Discussion}

The most common age in this study is $0-3$ years old age group at 16 patients (53.3\%). According to a study by Schindler, et al, states that pressure ulcer will be easier to form at the age of 2 years when entering the PICU hospital than older ages. ${ }^{11}$ Research by Schmidt, et al., and Curley, et al., also found that the average age of the ulcer was 36 months. ${ }^{11,12}$ Body composition differs between infant, child and adult populations and changes rapidly as the child grows and develops. In general, babies have fewer muscles and more fat than adults so the subcutaneous tissue is softer and easier to deform at the same pressure. ${ }^{13}$

The most common gender found in this study is males at 18 subjects $(60 \%)$ compated to women at $12(40 \%)$. Several epidemiological studies conducted in patients with infant and child ulcers, found that most patients were male. ${ }^{5}$ Possible explanations are due to the widespread availability and distribution of adipose tissue so that it also acts as a protective pad on the bony protrusion area for example on the sacrum, but this needs to be further studied later. ${ }^{14}$

In this study, the most common ulcer grade is grade 1 ulcer at 14 patients $(46.7 \%)$. This is similar to previous studies by Manning, et al., Curley, et al., and Mclane, et al., who found the highest is grade 1 ulcers in all patients. ${ }^{11,15,16}$ The location of the ulcer most often in this study is occipital for about 7 patients (23.3\%). Pressure ulcers in children are formed in the area of the body that holds the most pressure. Solis, et al., found that in all age groups, the pressure in the occipital area was the largest followed by the sacrum and scapula. ${ }^{17}$ In adults a different pattern was found, ischium, sacrum and tuberosity heel were the most frequent

Table 3. Sensitivity test in gram positive bacterial.

\begin{tabular}{|c|c|c|c|c|c|c|c|c|c|c|c|c|}
\hline \multirow{2}{*}{ Antibiotics } & \multicolumn{4}{|c|}{ Staphylococcus aureus $(n=4)$} & \multicolumn{4}{|c|}{ Kocuria kritinae $(n=1)$} & \multicolumn{4}{|c|}{ Enterococcus faecalis $(n=1)$} \\
\hline & $\mathbf{S}$ & $\%$ & $\mathbf{R}$ & $\%$ & $\mathbf{S}$ & $\%$ & $\mathbf{R}$ & $\%$ & $\mathbf{S}$ & $\%$ & $\mathbf{R}$ & $\%$ \\
\hline Amoxicillin & 0 & 0 & 4 & 100 & - & - & & & 0 & 0 & 1 & 100 \\
\hline Ampicillin/Sulbactam & 1 & 25 & 3 & 75 & 0 & 0 & 1 & 100 & 0 & 0 & 1 & 100 \\
\hline Cefuroxime & 1 & 25 & 3 & 75 & - & - & - & - & - & - & - & - \\
\hline Cefalexin & 0 & 0 & 3 & 100 & - & - & - & - & - & - & - & - \\
\hline Clindamycine & 3 & 75 & 1 & 25 & 0 & 0 & 1 & 100 & 0 & 0 & 1 & 100 \\
\hline Erythromycine & 3 & 75 & 1 & 25 & 0 & 0 & 1 & 100 & 0 & 0 & 1 & 100 \\
\hline Levofloxacine & 1 & 25 & 3 & 100 & 0 & 0 & 1 & 100 & 0 & 0 & 1 & 100 \\
\hline Trimethoprime/Sulfamethoxazole & 4 & 100 & 0 & 0 & - & - & - & - & - & - & - & - \\
\hline Tetracycline & 3 & 75 & 1 & 25 & 0 & 0 & 1 & 100 & 0 & 0 & 1 & 100 \\
\hline Vancomycine & 4 & 100 & 0 & 0 & 1 & 100 & 0 & 0 & 1 & 100 & 0 & 0 \\
\hline Moxifloxacine & 1 & 25 & 3 & 75 & - & - & - & - & - & - & - & - \\
\hline
\end{tabular}


Table 4. Sensitivity test in gram negative bacterial.

\begin{tabular}{|c|c|c|c|c|c|c|c|c|c|c|c|c|c|c|c|c|}
\hline \multirow{2}{*}{ Antibiotics } & \multicolumn{4}{|c|}{ Klebsiella pneumonia $(n=3)$} & \multicolumn{4}{|c|}{ Pseudomonas aeruginosa $(n=4)$} & \multicolumn{4}{|c|}{ Acinetobacter baumannii $(n=12)$} & \multicolumn{4}{|c|}{ Proteus mirabilis $(n=2)$} \\
\hline & S (n) & $\%$ & $\mathbf{R}$ (n) & $\%$ & $S(n)$ & $\%$ & $\mathbf{R}$ (n) & $\%$ & $\mathbf{S}(\mathbf{n})$ & $\%$ & $\mathbf{R}(\mathbf{n})$ & $\%$ & $S(n)$ & $\%$ & $\mathbf{R}(\mathbf{n})$ & $\%$ \\
\hline Amikacin & 3 & 100 & 0 & 0 & 2 & 50 & 2 & 50 & 4 & 100 & 0 & 0 & 1 & 50 & 1 & 50 \\
\hline Ampicillin & 0 & 0 & 3 & 100 & 0 & 0 & 4 & 100 & 0 & 0 & 4 & 100 & 0 & 0 & 2 & 100 \\
\hline Cefotaxime & 0 & 0 & 3 & 100 & 0 & 0 & 4 & 100 & 0 & 0 & 4 & 100 & 0 & 0 & 2 & 100 \\
\hline Ceftazidime & 0 & 0 & 3 & 100 & 0 & 0 & 4 & 100 & 0 & 0 & 4 & 100 & 0 & 0 & 2 & 100 \\
\hline Ceftriaxone & 0 & 0 & 3 & 100 & - & - & - & - & 0 & 0 & 4 & 100 & 0 & 0 & 2 & 100 \\
\hline Cefoperazone/Sulbactam & 1 & 33,3 & 2 & 66,7 & 1 & 33,3 & 3 & 66,7 & 3 & 75 & 1 & 25 & 1 & 50 & 1 & 50 \\
\hline Doxycycline & 2 & 66,7 & 1 & 33,3 & 0 & 0 & 4 & 100 & 2 & 50 & 2 & 50 & 0 & 0 & 2 & 100 \\
\hline Gentamycine & 0 & 0 & 3 & 100 & 1 & 33,3 & 3 & 66,7 & 0 & 0 & 4 & 100 & 0 & 0 & 2 & 100 \\
\hline Levofloxacine & 1 & 33,3 & 2 & 66,7 & 0 & 0 & 4 & 100 & 0 & 0 & 4 & 100 & 1 & 100 & 0 & 0 \\
\hline Meropenem & 2 & 66,7 & 1 & 33,3 & 1 & 33,3 & 3 & 66,7 & 2 & 50 & 2 & 50 & 2 & 100 & 0 & 0 \\
\hline Doripenem & 2 & 66,7 & 1 & 33,3 & 1 & 33,3 & 3 & 66,7 & 2 & 50 & 2 & 50 & - & - & - & - \\
\hline Tobramycine & 0 & 0 & 3 & 100 & 1 & 33,3 & 3 & 66,7 & 0 & 0 & 4 & 100 & 0 & 0 & 2 & 100 \\
\hline
\end{tabular}

\begin{tabular}{|c|c|c|c|c|c|c|c|c|c|c|c|c|}
\hline \multirow{2}{*}{ Antibiotics } & \multicolumn{4}{|c|}{ Serratia marcescens $(n=1)$} & \multicolumn{4}{|c|}{ Providencia stuartii $(n=1)$} & \multicolumn{4}{|c|}{ Burkholderia cepacia $(n=1)$} \\
\hline & S(n) & $\%$ & $\mathbf{R}(\mathbf{n})$ & $\%$ & S(n) & $\%$ & $\mathbf{R}(\mathbf{n})$ & $\%$ & S(n) & $\%$ & $\mathbf{R}(\mathrm{n})$ & $\%$ \\
\hline Amikacin & 1 & 100 & 0 & 0 & 1 & 100 & 0 & 0 & 0 & 0 & 1 & 100 \\
\hline Ampicillin & 0 & 0 & 1 & 100 & 0 & 0 & 1 & 100 & 0 & 0 & 1 & 100 \\
\hline Cefotaxime & 0 & 0 & 1 & 100 & 0 & 0 & 1 & 100 & 0 & 0 & 1 & 100 \\
\hline Ceftazidime & 0 & 0 & 1 & 100 & 0 & 0 & 1 & 100 & 0 & 0 & 1 & 100 \\
\hline Ceftriaxone & 0 & 0 & 1 & 100 & 0 & 0 & 1 & 100 & 0 & 0 & - & - \\
\hline Cefoperazone/Sulbactam & 0 & 0 & 1 & 100 & 0 & 0 & 1 & 100 & 0 & 0 & 1 & 100 \\
\hline Doxycycline & 0 & 0 & 1 & 100 & 0 & 0 & 1 & 100 & 0 & 0 & 1 & 100 \\
\hline Gentamycine & 0 & 0 & 1 & 100 & 0 & 0 & 1 & 100 & 0 & 0 & 1 & 100 \\
\hline Levofloxacine & 1 & 100 & 0 & 0 & 1 & 100 & 0 & 0 & 0 & 0 & 1 & 100 \\
\hline Meropenem & 0 & 0 & 1 & 100 & 0 & 0 & 1 & 100 & 0 & 0 & 1 & 100 \\
\hline Doripenem & 0 & 0 & 1 & 100 & - & - & - & - & - & - & - & - \\
\hline Tobramycine & 0 & 0 & 1 & 100 & 0 & 0 & 1 & 100 & 0 & 0 & 1 & 100 \\
\hline
\end{tabular}

locations. ${ }^{5,18}$ This difference is caused by differences in anatomy. Solis, et al., stated that the location of the most severe pressure would change with age and growth from the occipital to the sacrum region. ${ }^{19}$

The most frequent onset of ulcers is 3-5 weeks in 10 patients (50\%). Research by Manning, et al., also found that the average duration of time for patients to develop a pressure ulcer was around 24 days, while an increase in length of stay would also increase the risk of a pressure ulcer. $^{15}$

The most common disease in this study is caused by Hidrocephalus, at 5 patients (16.6\%). Immobility and decreased sensation are major factors in the formation of child ulcers. ${ }^{4}$ Both of these can be found in patients with hydrocephalus.

The most common bacteria found in this study is Acinetobacter baumannii found in 12 patients (40\%). Acinetobacter baumannii is a gram-negative bacteria that is aerobic, pleomorphic and non-motile. These bacteria are opportunistic and are associated with hospital- acquired infections. ${ }^{20}$ In general, if gram-negative and positive bacteria are compared, the most germs are gramnegative bacteria. The same was found in the study held by Cahyopoetra, et al., where the most common cause of pressure ulcers in Wahidin Sudirohusodo Hospital was gram-negative bacteria. ${ }^{21}$

The results of bacterial sensitivity test to antibiotics were divided based on gram negative and positive germs. In gram-negative bacteria, the highest resistance was found to ampicillin, ceftriaxone, ceftazidine and cefotaxim. The highest sensitivity was found to amikacin. High antibiotic resistance may be due to self-medication practices, lack of laboratory diagnostic services or unavailability of drug management guidelines related to drug selection resulting in improper use of antibiotics. ${ }^{19}$ In gram-positive bacteria, the highest resistance is found to amoxicillin, ampicillin/sulbactam, cefuroxime, cefalexin, ciprofloxacin, levofloxacin and moxifloxacin. The highest sensitivity was found to vancomycin. The most common grampositive bacteria is Staphylococcus aureus, with the highest 
resistance to penicillin antibiotics, this was investigated in the study of Mama, et al., and Mulu in Ethiopia. ${ }^{19,22}$ The high sensitivity of gram-positive bacteria to vancomycin may be due to lack of use of this antibiotic, lack of availability of these drugs, and consideration of the costs and effects of the poison. $^{22}$

\section{Conclusion}

The most common bacterial in pressure ulcers is Acinetobacter baumanii. The most sensitive antibiotics from all gram positive bacterial is Vancomycine. The most sensitive antibiotics from all gram negative bacterial is amikacine. The limitation of this study is the small number of patients.

\section{Acknowledgement}

Research Foundation of Universitas Sumatera Utara Budget Period of 2017 supported this research. We thank our colleagues from Department of Dermatology and Venereology, Faculty of Medicine, Universitas Sumatera Utara, Haji Adam Malik General Hospital, and Microbiology Laboratory who provided insight and expertise that greatly assisted the research.

\section{References}

1. National Pressure Ulcer Advisory Panel and European Pressure Ulcer. Prevention and Treatment of Pressure Ulcers: Clinical Practical Guideline National Pressure Advisory Panel. Washington DC: National Pressure Ulcer Advisory Panel; 2009.

2. Schluer AB. Pressure ulcers in maturing skin-a clinical perspective. J Tissue Viability. 2016; 26(1): 2-5.

3. Baharestani MM, Pope E. Chronic wounds in neonates and children. In: Krasner D, Rodeheaver G, Sibbald G, Eds. Chronic Wound Care. Malvern: HMP Communications; 2007. p.679-93.

4. Willock J, Askew C, Bolland R, Maciver H, James N. Multicenter research: lessons from the field. J Pediatr Nursing. 2005; 17(10): 31-3

5. Kottner J, Wilborn D, Dassen T. Frequency of pressure ulcers in the pediatric population: a literature review and new empirical data. Int J Nursing Studies. 2010; 47(10): 1330-40.

6. Suddaby E, Barneu S, Facteau L. Skin breakdown in acute care pediatrics. Pediatr Nursing. 2005; 31(2): 132-8.
7. Dellinger RP, Levy MM, Rhodes A, Annane D, Gerlach H, Opal $\mathrm{SM}$, et al. Surviving sepsis campaign: international guidelines for management of severe sepsis and septic shock. Inten Care Med. 2012; 39: 165-228

8. Willock J, Maylor M. Pressure ulcers in infants and children. Nursing Standard. 2004; 24(18): 56-62.

9. Cataldo C, Bonura C, Caputo G, Aleo A, Rizzo G, Geraci DM, et al. Colonization of pressure ulcers by multidrug-resistant microorganism in patients receiving home care. Scand J Infect Dis. 2011; 43(11-12): 947-52.

10. Brook I. Microbiology and management of decubitus ulcers in children. J Developmental Phys Disabil. 2004; 16(3): 297-305.

11. Curley MA, Razmus IS, Roberts KE, Wypij D. Predicting pressure ulcers risk in pediatric patients the Braden Q scale. Nurs Res. 2003; 52(1): 22-33.

12. Schmidt JE, Berens RJ, Zollo MB, Weisner M, Weigle CG. Skin breakdown in children and high frequency oscillatory ventilation. Arch Phys Med Rehabil. 1998; 79: 1565-9.

13. Levy A, Kopplin K, Gefen A. Adjustability and adaptability are critical characteristics of pediatric support surfaces. Adv Wound Care. 2015; 4(10): 615-22.

14. Primiano M, Friend M, McClure C, Nardi S, Fix L, Schafer M, et al. Pressure Ulcer Prevalence and Risk Factors among Prolonged Surgical Procedures in the OR. AORN Journal. 2011; 94(6): 555 66.

15. Manning M, Gauvreau K, Curley M. Factors associated with occipital pressure ulcers in hospitalized infants and children. Am J Crit Care. 2015; 24(4): 342-8

16. McLane KM, Bookout K, McCord S, McCain J, Jefferson LS The 2003 national pediatric pressure ulcer and skin breakdown prevalence survey: a multisite study. J Wound Ostomy Continence Nurse. 2004; 31(4): 168-78.

17. Solis I, Krouskop T, Trainer N, Marburger R. Supine interface pressure in children. Arch Phys Med Rehabil. 1988; 69(7): 524-6.

18. Vanderwee K, Clark M, Dealey C, Gunningberg L, Defloor T. Pressure ulcer prevalence in Europe: a pilot study. J Eval Clin Pract. 2007; 13(2): 227-35

19. Mama M, Abdissa A, Sewunet T. Antimicrobial susceptibility pattern of bacterial isolates from wound infection and their sensitivity to alternative topical agents at Jimma University Specialized Hospital, South-West Ethiopia. Ann Clin Microbiol Antimicrob. 2014; 13: 14 doi: 10.1186/1476-0711-13-14.

20. Howard A, O'Donoghue M, Feeney A, Sleator RD. Acinetobacter baumannii: an emerging opportunistic pathogen. Virulence. 2012 3(3): $243-50$

21. Cahyopeotro A, Sarimin S, Seweng A. Identifikasi pola kuman dan tes resistensi antibiotic pada penderita ulkus dekubitus di RS Wahidin Sudirohusodo [Thesis]. Makassar: Universitas Hasanuddin; 2014.

22. Mulu A, Moges F, Tessema B, Kassu A. Pattern and multiple drug resistance of bacterial pathogens isolated from wound infection at University of Gondar Teaching Hospital, Northwest Ethiopia. Ethiop Med J. 2006; 44(2): 125-131. 